\title{
Management of Technology Transfer in the Context of Globalization Using Software Composition Methods
}

\author{
Crenguta Ileana SINISI ${ }^{\star}$
}

\begin{tabular}{l}
\hline \multicolumn{1}{c}{ A R T I C L E I N F O } \\
\hline Article history: \\
Accepted April 2021 \\
Available online May 2021 \\
\hline JEL Classification \\
M1, M11, M15, M21, M20 \\
Keywords: \\
Development, Innovation, \\
Creativity, Machinery
\end{tabular}

\begin{abstract}
A B S T R A C T
Intelligent power distribution, integrated safety, switching, and diagnostic functions, all in one component. The functionalities can be designed to be both electronic and hybrid (electronic and electrical). Draexlmaier offers solutions that are integrated into existing distributors or can be installed separately in the vehicle. Draexlmaier is developing ideas, concepts, and an assembly kit for the 48-volt electrical wiring system to enable rapid adaptation to customer requirements and therefore implementation in series production. Using the 48-volt power distributor, new installation spaces can be used and weighing can be saved by replacing the relays. The central control unit of the Draexlmaier group controls the entire lighting of the vehicle, as well as various comfort and safety functions. The control unit connects various bus systems in the vehicle, from the drive train to the instrument panel to the Car2Cloud connection.
\end{abstract}

(c) 2021 EAI. All rights reserved.

\section{Introduction}

The management of innovation and technology transfer is a sum of knowledge of the engineer, in general, respectively of the technology transfer engineer concerned with activities specific to the development of new products and the processes encountered in carrying out projects specific to promoting these products. The notion of the product has a broader meaning. Thus, the by-product is meant a good material, a technology, or a service. [1]

Often, in development of a service is involved the development of both good material and technology.

Sometimes, the development of a "good material" also leads to the development of appropriate manufacturing technology. The amount of knowledge is in the possession of practitioners, staff in design departments, researchers and development institutions, and academics who apply and promote it. Like other professions such as engineering, law, medicine, or accounting, the notions of innovation management involve knowledge and practices, verified over the years, with a wide application in both innovative processes, design of new products, technologies, or services, and in other areas. The team that will work on this new project always needs to establish the most appropriate activities to achieve the objectives of the stage and also to get the final goal of the project to achieve a new product, service, or technology. [5]

The innovation need is given by the requirements and demands of the development and management of new products and services, which are determined by the existence of international competition, increasing consumer demand, the rapid development of technological development, and new norms and standards on environmental protection, good practices, etc.

Innovation is the most important success factor in intense competition between companies, being advantageous only to companies that have gained new competitive advantages.

\subsection{Definitions and notions of innovation}

Successful products can be obtained by those companies that are able to organize innovation according to success factors and ensure their implementation efficiently, in terms of terms and costs.

Integrated Product Development (IPD) is a management method that takes into account all success factors. The basic concept of DPI is the coordinated establishment of all resources and processes, which are necessary for successful creation and effective marketing. This includes specific procurement processes for product, production, marketing, and quality control logistics.

The global DIP concept supports product creation from idea to successful commercial launch. DPI can be used for the development of products/services and supports the development of essential innovative resources (core competencies, organization, strategy, etc.).All the components that are needed to create 
successful goods and services together form the system of goods and services. The interaction between these components is crucial for the success of the new product.

\subsection{Basic components and types of innovation}

The processes include:

- managerial-organizational processes,

- technological processes,

- marketing processes.

Ultimately, the marketing processes are also managerial processes, CONSISTING IN THE PROMOTION OF SOME PRODUCTS ON THE MARKET through different methods such as design for example. In this situation we find four types of innovation such as: product innovation, process innovation, marketing innovation, and organizational innovation. Product and process innovation are closely linked to the concept of product or process technological innovation. Marketing and organizational innovation cover a wide range of innovations, which may exceed the limits of the above definitions. Product innovation is the introduction of a good or service, which is new or significantly improved while respecting their characteristics or intention to use them. This includes significant improvements in technical specifications, components and materials, built-in software, user-friendly use, and other functional features. Product innovation may use new knowledge or technologies and it can be based on new uses or both of existing knowledge and technologies. The term "product" is used to cover a wide range of goods and services. [8]

The introduction of the ABS braking system and the Global Positioning System (GPS) navigation system, or other improvements to cars, are examples of product innovation, consisting of partial changes or additions to a number of integrated technical subsystems.

\subsection{Integrated product development}

The global DIP concept supports product creation from idea to successful commercial launch. DPI can be used for the development of products / services and supports the development of essential innovative resources (core competencies, organization, strategy, etc.).[7]

All the components that are needed to create successful goods and services together form the system of goods and services (Figure 1.1). The interaction between these components is crucial for the success of the new product.

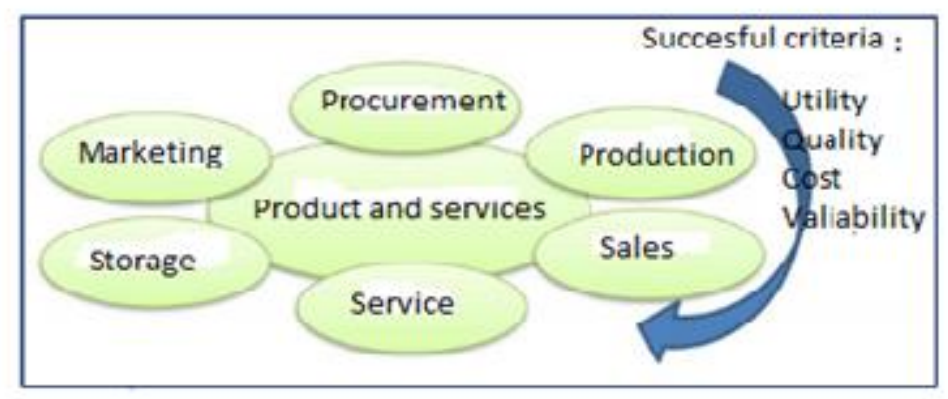

Figure 1.1. Development of services

(Source: own content)

\subsection{The "House of Innovation" model}

Based on the experience of innovation consulting, A.T. Kearney developed the "House of Innovation" model (figure 1.2). This model shows the most important modules of successful innovation management. The "roof" of the house is the innovation strategy, a planning process that clearly defines what innovation goals are needed and how they can be supported by resources, processes, technologies, and behaviors within the company. An innovation-oriented company must include these goals in its organization and culture. 


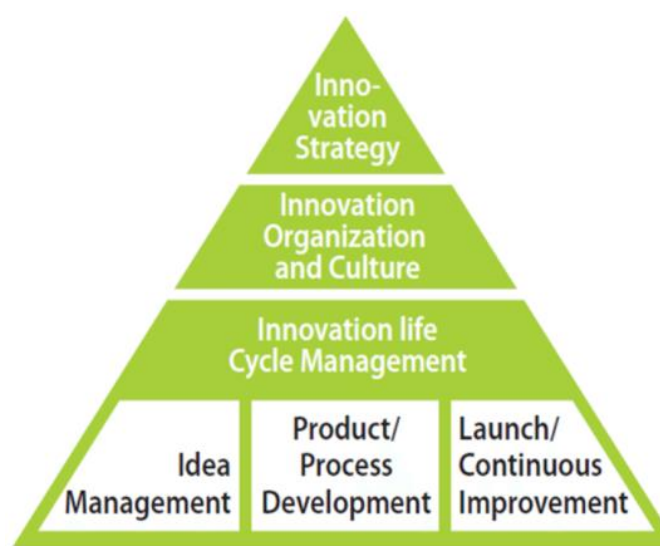

Figure 1.2. The model "House of innovation" (Source: the house of innovation)

\section{Entrepreneurial innovation}

Creativity and innovation are the specific tools of the entrepreneurial system. It is the act that endows the system with a new ability to create wealth. Innovation creates a means, the use of which endows something of nature with economic value. One example, given by Peter F. Drucker, is particularly eloquent: "Until a century ago, neither the mineral oil that came out of the earth nor the bauxite - the ore from which aluminum is extracted - were a means. There were some inconveniences: both made the earth infertile. The mold was a calamity, not a means. [7]

Bacteriologists made a desperate effort to protect their cultures from bacteria against contamination with this fungus. Then, in the 1920s, a London doctor, Alexander Fleming, realized that this was exactly the bacterial destroyer that bacteriologists were looking for, and the mold became a valuable means ".The same case aplies to the social and economic spheres. There are no greater resources in the economy than "purchasing power." But purchasing power is the creation of an innovative entrepreneur.

\subsection{The process of technology transfer}

Technology transfer in the form of manufacturing technology transfer involves a series of formal and informal relations between research and development units and the public and private economic sectors. The purpose of the transfer is to strengthen the economy in a territory, by accelerating the application of new technologies and resources, to meet the needs and opportunities of the private and public sectors.[17]

The technology transfer is the process by which existing knowledge facilities or capabilities, that were funded from public research and development funds, are used to meet both public and private needs. As a purpose, among the results of successful technology transfer processes, we can highlight the improvement of products, the efficiency of services, the improvement of manufacturing processes, the realization of new products for sale on national and international markets.

Thus, the transfer of technology is perceived, in the most general sense, as the transfer of research results from research and development units (universities, research institutes) to business companies or other components of society.

\subsection{ITT - From market to market}

From the market to the merchandise plan suggestions and data received from the market cause the initiative to search out a replacement plan. the corporate is responsive to a haul, the feedback from the client additionally brings helpful suggestions and on this basis, new opportunities area unit known. Such info additionally comes from the market research commissioned by the corporate. Next, artistic groups intervene to support firms within the method of characteristic the thought.

\section{Software program}

Software means a system of computer programs including their application procedures, a system provided with that computer or subsequently created by the user or purchased commercially. By contrast, the word hardware refers to the physical part of that computer or computer system. In general, in order to work, a computer system needs both components, in addition to the data to be processed. Sometimes this data is also considered to be part of the software.[16]

The software component can include the full range of programming products, usually consisting of operating systems, drivers, and application programs. In some special cases, parts of the software are incorporated from the construction into the hardware - by using preprogrammed integrated circuits.

In some areas, software refers primarily to the data that devices or computers work with, such as digitized images, sounds and music, computer games, digitized movies, videos, and many other similar data. In extreme cases, even physical data carriers or "media" are considered to be "software", such as CD and DVD optical discs, VHS and MiniDV videotapes, audiotapes, and so on. 
The results of this stage is that the product plan, that is subjected to the analysis method, so as to develop new helpful merchandise.

\subsection{From product idea to product}

At this stage of the product development process, specific products are developed based on ideas and processes for their production. The product is developed "ready for production" and "ready for the market" The difficulties and risks need to be clarified in order to implement the new concepts promoted.

\subsection{From product to market}

This last stage describes the particular market implementation of associate degree innovative service or product and therefore the cycle is complete.

What is product development?

The objective of the research - development activity consists in maximising the economic activity of the corporate, by making new merchandise or new technologies that may result in the best realization of the merchandise. In several engineering fields, the event of activities and processes area unit the results of a historical evolution. Consequently, the event of most processes of act has marked the applying of scientific laws and principles over time.

The operation of launching associate degree innovative product is most frequently applied in 3 main phases: distinguishing the opportunities and therefore the context during which the new product is intended, its realization and its transposition into observe.

It is aforesaid that the engineer faces laws and principles in effecting his activities, which has the event of latest merchandise. Hence, the scientific part of the event of any innovative product.

The development of a product represents the totality of scientific activities, by applying specific laws, rules and scientific principles, ranging from the concept of constructing a replacement product, informative and elucidating the theme and ending with validation (approval and certification) for the aim of introduction into producing. Product development-specific activities area unit in a very continuous interaction with the extent of previous and collateral information. On the opposite hand, the activities applied within the development of any product area unit applied on the premise of specific methodologies that have a organized character.

Often, within the method, the applied methodology includes consecutive steps. It ought to be noted that the methodology implicitly includes the scientific aspect by: applying specific laws, rules and scientific principles, to that area unit usually supplemental engineering science and aesthetic principles (rules). Relevant is that the undeniable fact that the methodology of the processes specific to development relies on expertise within the field. The artistic spirit, intuition and knowledge of the work team area unit decisive in terms of product quality developed even within the context of applying scientific principles.

Basically, the expertise of the team members is related to the applying of laws and scientific principles within the race to get a replacement product, in associate degree obligatory amount of your time. The solutions offered to the market should have a high use price, be economical, have minimum prices throughout the life cycle, thus on absolutely meet the customer's needs. For the development of a quality product and for the increase of its use value, the methodical application of knowledge based on experience is always decisive. Starting from the idea of making a new product, the stages and activities specific to the development of innovative products are presented in Figure 1.3

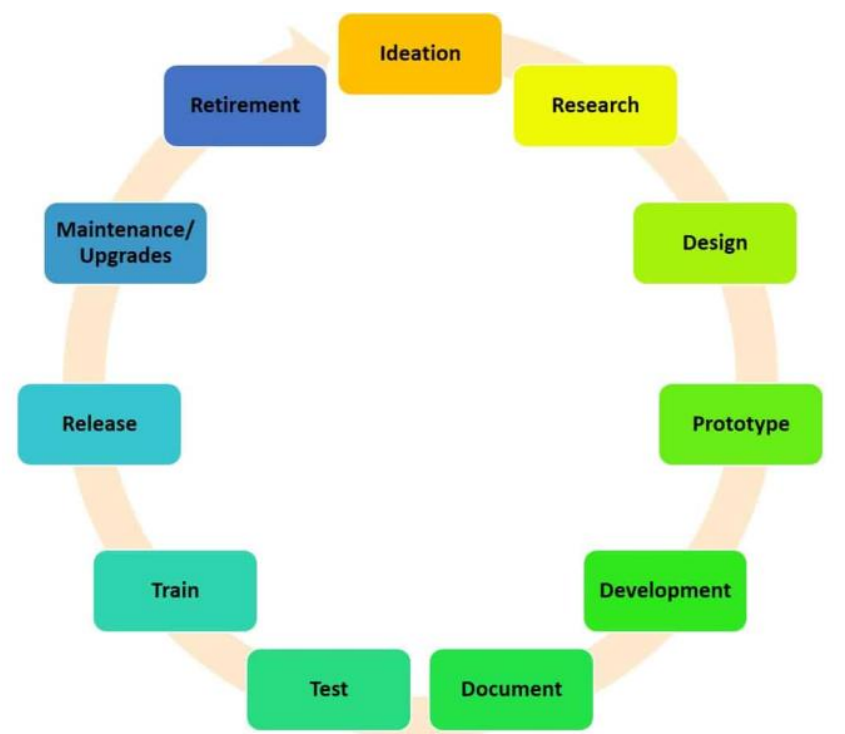

Figure 1.3. The Flow of the new product in development (Source: Product Development Process 101) 


\section{Technology transfer}

Software is that the term utilized in the technical field to outline pc applications (computer programs) accustomed command and management any electronic system. The OS could be a class of software system that gives variety of basic functions and services for user-level pc applications. AN OS is that the soft interface between the user and therefore the electronic system he controls. the road between high-level and low-level descriptions isn't fine drawn. Sometimes, if a very important technical detail must be such, it'll seem within the document.

However, this should be the exception and not the rule. These exceptions is also thanks to the requirement to take care of compatibility with alternative existing systems, or to sure choices desired by the client, like the employment of a precise customary or a constraint on the image size of the appliance, which can be supposed for a special class of users or which is able to run on systems with variety of options (monitors that don't support high resolutions).[20]

The design document describes the requirements implementation plan. Details on programming languages, development environments, memory size, platform, algorithms, data structures, global definitions, interfaces, etc. are identified.

\subsection{Testing}

The quality of the code is extremely vital. However, several corporations haven't learned this and turn out systems with in depth practicality however caliber. it's easier to clarify to the client why a particular perform is missing than to clarify why the merchandise isn't performing arts.

A customer satisfied with the quality of the product will remain loyal to the company and will wait for the new functions in the next versions. In many programming engineering methodologies, the testing phase is a separate phase, performed by a different team after the implementation is complete.

The reason is that a programmer cannot easily discover his own mistakes. A new person looking at the code may discover obvious mistakes that escape the one who reads and rereads the material many times. Unfortunately, this practice can lead to an indifferent attitude towards quality in the implementation team. Testing techniques are mainly approached from the perspective of the system manufacturer. Ideally, the client should also play an important role in this phase.

\subsection{Battery management systems}

The battery control unit integrated in the high voltage control box of the Draexlmaier Group is the interface between the machine and the battery. Here, the received battery data is measured, processed, calculated, diagnosed and communicated. From the measured input values, the battery control unit calculates the state of charge (SoC), the state of health $(\mathrm{SoH})$ and the state of operation (SoF) of the battery. In addition, the control unit contains an insulation resistance monitoring system and takes over the thermal management. DIUS current and voltage sensor.

With the help of the current and voltage sensor, or dIUS, the Draexlmaier Group has developed a future-oriented, high-precision and safety measuring unit with an extended diagnostic function. The sensor offers extremely accurate measurement of voltage and current in a high voltage battery, while occupying a very small space and taking into account electrical safety. This applies to the entire life of the product. For cell monitoring and balancing, Draexlmaier offers an integrated solution as well as an external solution according to customer specifications. [9]

The cell controller measures and monitors the safety and temperature values relevant to the voltage in the individual cells and takes over the cell balancing to protect the cells from overload or overload. Draexlmaier offers solutions that are integrated into existing distributors or can be installed separately in the vehicle. The scope varies from the "B +" distributor to small spaced distribution plates. In order to achieve a rapid adaptation to customer requirements and to implement ready-to-use solutions, Draexlmaier is constantly developing new ideas and concepts. With the help of fuses and electronic switches, weight can be saved and new installation areas will be used. In addition, a quick fault analysis is activated by diagnostics, for example in the repair shop. The intelligent power distribution is done depending on the charging condition or alternatively by prioritization.

\subsection{Interior and body electronics}

For the intelligent RGB LED, the Draexlmaier Group has developed an innovative lighting technology for the implementation of lighting scenarios. Atmospheric lighting, with an exclusive look, conveys well-being and an elegant atmosphere.

Whether it's inside an airplane or a car, a train compartment, a ship's cabin, furniture or bars - the microprocessor-controlled RGB LED offers virtually unlimited individuality. Through the patented individual control of the three basic colors red, green and blue, a flexible display of colors and color changes is possible. Innovative operating concepts, such as capacitive or even contactless gesture recognition, integrated into the Draexlmaier interior components, complete the range of functions. From development to production, Draexlmaier offers everything from a single source. 
Central control unit. The central control unit of the Draexlmaier group controls the entire lighting of the vehicle, as well as various comfort and safety functions. The control unit connects various bus systems in the vehicle, from the drive train to the instrument panel to the Car2Cloud connection. [3]

\subsection{Test application}

In the following, a test application model for electrical and electronic wiring will be presented, which the company can use in production areas. The application will have the final purpose of notifying the workers if the wiring made on the workbenches is functional. In addition to the software application's decision to show the correct wiring, the program will be able to show on the work screen the measured values of the passive components (resistors, capacitors, coils) but also the functionality of the relays and switches.[2]

The application is a testing platform of the company Draexlmaier for testing electrical and electronic wiring and components and other functional elements in the production of automobiles. The application can verify the correct functionality of the components by testing at the end of the production line. The software can be classified as a production chain management testing system represent like in Figure 1.4.

The system mentioned above consists of:

- $\quad$ software components (the application itself and other adjacent applications);

- hardware components (sensors, fiber optics, etc.);

- $\quad$ hardware components, called test adapters, that help make the final decision.

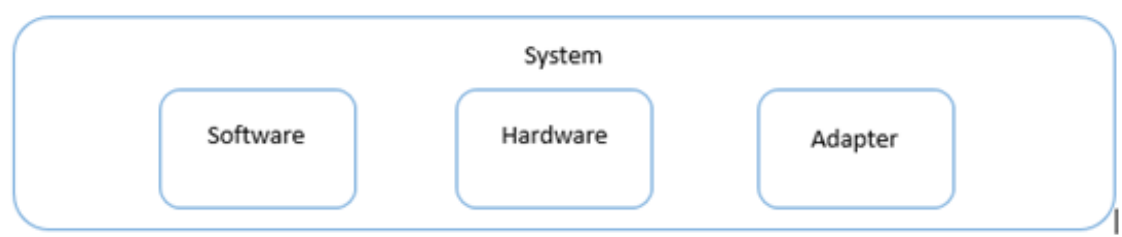

Figure 1.4. Composition of the test sistem

(Source: Tehnical analysis of the financial markets)

The application works with other adjacent applications, with which the following can be done:

- Application A which can create documents in which test sets are defined;

- $\quad$ Application A -> Document A which can be called document_A_test

- Application B that can read the hardware components that make up the system and can create a document with those components;

Application B -> Document B which can be called document_B_hw

- Application $\mathrm{C}$ that can create or edit a document containing the test flow;

- $\quad$ Application C -> Document C which can be called document_C_flux.

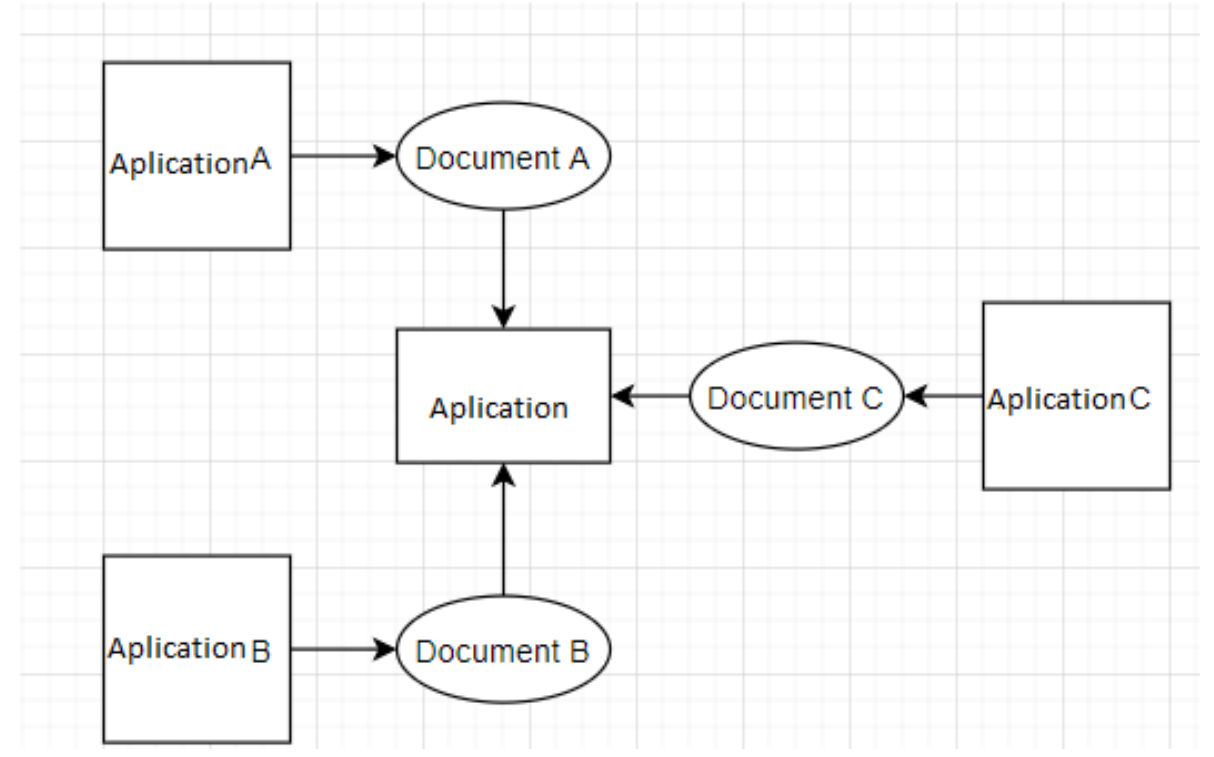

Figure 1.5. The composition of the software sistem

(Source:wwwdraxelmaier.com) 
Application A is used as a multitude of configuration tools. It is used by test programmers.

Document $A$ is the file resulting from Application A, the output file.

Application B is used to configure the hardware components of the test systems. With the application you can create or edit document $B$.

In the $\mathrm{C}$ application, test streams are defined and modified using the document $\mathrm{C}$ flux file. The file is used in the central software application which, in its component that processes the data of the test flow.

The central application contains different operating areas. Depending on the operating area, the user can choose between different working modes. For each mode of operation there are several sub-modes of production.

Depending on the hardware and configuration, a test system may operate to test the following:

- correct wiring of low voltage electrical wiring;

- correct wiring of high voltage electrical wiring;

- the presence of the necessary clips (on the machine) on the wiring;

- electronic components in a wiring (resistors, capacitors, etc.);

- functional components in a wiring harness (relays, fuses, etc.).

The operating mode of the system can also be selected during the installation and configuration of the test system. Some modes of operation also allow specific variants.

The operating modes, along with the specific variants, are the following:

- electrical system

- pressure check

- high voltage

- high frequency

- electrical system + parallel system

- functional system

The operating mode of the system can also be selected during the installation and configuration of the test system. Some modes of operation also allow specific variants.[21]

The operating modes, along with the specific variants, are the following:

- electrical system

- pressure check

- $\quad$ high voltage

- high frequency

- electrical system + parallel system

- functional system

\subsection{Battery management systems}

Scalable battery systems include up to 20 electronic components for efficient monitoring, measurement and control of all safety and customer-relevant functions. Draexlmaier Group's battery electronics include the battery control unit, including insulation monitoring and thermal management, voltage and voltage sensors, and cell voltage measurement and monitoring.

Battery control unit. The battery control unit integrated in the high voltage control box of the Draexlmaier Group is the interface between the machine and the battery. Here, the received battery data is measured, processed, calculated, diagnosed and communicated. From the measured input values, the battery control unit calculates the state of charge ( $\mathrm{SoC}$ ), the state of health (SoH) and the state of operation (SoF) of the battery. In addition, the control unit contains an insulation resistance monitoring system and takes over the thermal management.[16]

DIUS current and voltage sensor. With the help of the current and voltage sensor, or dIUS, the Draexlmaier Group has developed a future-oriented, high-precision and safety measuring unit with an extended diagnostic function. The sensor offers extremely accurate measurement of voltage and current in a high voltage battery, while occupying a very small space and taking into account electrical safety. This applies to the entire life of the product.

Cell controller. For cell monitoring and balancing, Draexlmaier offers an integrated solution as well as an external solution according to customer specifications. The cell controller measures and monitors the safety and temperature values relevant to the voltage in the individual cells and takes over the cell balancing to protect the cells from overload or overload.

\subsection{Intelligent energy distributors}

Intelligent power distribution, integrated safety, switching and diagnostic functions, all in one component. The functionalities can be designed to be both electronic and hybrid (electronic and electrical).

Draexlmaier offers solutions that are integrated into existing distributors or can be installed separately in the vehicle. The scope varies from the "B +" distributor to small spaced distribution plates. In 
order to achieve a rapid adaptation to customer requirements and to implement ready-to-use solutions, Draexlmaier is constantly developing new ideas and concepts.[10]

With the help of fuses and electronic switches, weight can be saved and new installation areas will be used. In addition, a quick fault analysis is activated by diagnostics, for example in the repair shop. The intelligent power distribution is done depending on the charging condition or alternatively by prioritization.

The 48-volt voltage level brings new challenges for the electrical system and power distribution and increases the requirements for electrical components. Arc light in series and parallel are more likely and must be recognized and handled safely. Tasks can be switched and secured electronically and included in an intelligent energy management system.[11]

Draexlmaier is developing ideas, concepts and an assembly kit for the 48-volt electrical wiring system to enable rapid adaptation to customer requirements and therefore implementation in series production. Using the 48-volt power distributor, new installation spaces can be used and weighing can be saved by replacing the relays.[13]

\section{Conclusion}

The steps taken by the company followed several priority directions validation of some banchmarking tools and the need to modify them, taking over some suggestions for improvement made by the company's representatives, testing the effectiveness of benchmarking techniques and tools for identifying target partners and selecting effective partners, based on objective criteria, initiating a process of continuous improvement aimed at research, design, development of complex technologies, assisted design for equipment and technologies, the considerable improvement of the company's competitive position on the market, identifying a core capable of amplifying benchmarking techniques and tools and of organizing and monitoring changes within the company, constantly completing and updating the database, used in this research, with data on best practices, verification of benchmarking research for the preparation of specifications in order to purchase technologies / equipment and for the comparative analysis of offers.

The courses / trainings can be adapted both according to the employees' schedule and according to the company's needs. By giving employees access to new sources of training, the company's activity can be improved both qualitatively and quantitatively, and employees, although they will go through a reduction in the salary package, will have a high degree of satisfaction. , taking into account the fact that the access to most of these courses (+ certifications) is made for a fee, this costing a lot at present. In the future, we intend to implement other software programs to improve the quality of the company's products in Romania.[3]

\section{References}

1. Aivaz, K. A., (2020). Considerations on Asset Management and Turnover Factorial Correlations: The Case of Dobrogea Region, Romania.

2. Aldecoa, Francisco and Michael Keating,(1999). The Foreign Relations of Subnational, Ed. Paradiplomacy, University of Maribor.

3. Audretsch, D. B., Hülsbeck, M., \& Lehmann, E. E., (2012). Regional competitiveness, University Spillovers, and Antrepreneurial Activity. Small Business Economics, 39(3), 587-601.

4. Audretsch, D. B., Keilbach, M. C., \& Lehmann, E. E., (2006). Entrepreneurship and economic growth, Oxford University Press.

5. Audretsch, D. B., Lehmann, E. E., \& Warning, S., (2005). University Spillover and New Firm Location, Research Policy, 34(7), 1113-1122.

6. Audretsch, D. B., Lehmann, E. E., \& Wright, M., (2014). Technology transfer in a global economy. The Journal of Technology Transfer, 39(3), 301-312.

7. Audretsch, D. B., Lehmann, E. E., Link, A. N., \& Starnecker, A., (2013). Technology transfer in a global economy. , Small Bussines Economics.

8. Audretsch, D., Lehmann, E., \& Warning, S., (2004). University Spillovers and New Firm Location. Max Planck Institute of Econo mics, Entrepreneurship, Planck Institute of Economics, Entrepreneurship, Growth and Public Policy Group.

9. Azagra-Caro, J. M., Pardo, R., \& Rama, R., (2014). Not searching, but finding: how innovation shapes perceptions about universities and public research organisations. The Journal of Technology Transfer, 39(3), 454-471.

10. Chan, A. P., \& Chan, A. P., (2004). Key performance indicators for measuring construction success. Benchmarking: an international journal, Contribution to Journal.

11. Dan, M. C., (2012). Clusterele inovative: o soluţie pentru dezvoltarea economică a României. Economie teoretică și aplicată, $19(9)$ ), 574.

12. Ilieș, L., (2003), Managementul calității totale, Ed. Dacia, Cluj-Napoca.

13. Imai, M., (2004). Kaizen: the key to Japan's competitive success. 1986. DE WIT, B.; MEYER, R. Strategy: Process, Content, Context. An international perspective. Minneapolis/St. Paul: West Publishing Company.

14. Möller, K., (2010). Sense-making and agenda construction in emerging business networks-How to direct radical innovation. Industrial Marketing Management, 39(3), 361-371.

15. Sinisi, C.I., (2017). Management of Technology Transfer in the Context of Globalization, Digital Book.

16. Sinisi, C.I., (2020). Integrarea managementului calității, strategiei și inovării în spațiul economic, Editura Economică, București.

17. Tomescu C.I., (2008). Managementul Inovarii, Editura SITECH, Craiova.

18. Zoltan J. A., \& Preston, L. (1997). Small and medium-sized enterprises, technology, and globalization: Introduction to a special issue on small and medium-sized enterprises in the global economy. Small Business Economics, 9(1), 1-6. 